\title{
The Research on the Innovative Path of International Talent Training in Local Normal College
}

\author{
Jin-fang LI \\ School of Business, Luoyang Normal University, Luoyang 471934, China \\ jinfang8866@163.com
}

\begin{abstract}
Keywords: Chinese-foreign cooperation in running schools, international talent, local normal colleges, free trade zone

Abstract. With the development of the free trade zone and the Belt and Road, local normal colleges need to cultivate international talents. At present, there are still some problems in the training of international talent for applied majors in local normal colleges, such as the difficulty in choosing cooperative running-school objects, the lack of effective integration of internationalization and localization, and the need to strengthen the management team of professional student education. To this end, the local normal college should make innovations in such aspects as prudent selection of cooperative school-running objects to promote the integration of educational and cultural concepts, broadening the path of international talent cultivation based on industry-education-research orientation, and building a scientific talent evaluation system. Then it would cultivate high-quality applied international talents for the external development of local economy.
\end{abstract}

\section{Introduction}

In July 2016, the ministry of education of China issued the "education action of promoting the construction of the Belt and Road", which aims to continuously expand the opening up of the educational field, promote education development and economic and trade cooperation go hand in hand and give full play to the role of soft power in education. The project of Chinese-foreign cooperation in running schools is one of the important carriers of the opening up of China's higher education in the new era. It shoulders the responsibility of cultivating morality, helping students to establish correct world view, outlook on life and values, cultivating their outstanding traditional cultural literacy of the Chinese nation to enhance their sense of national pride and self-confidence, and strengthening the mission of builders and successors of socialist cause.

The local normal colleges should actively develop the project of Chinese-foreign cooperation in running school. Firstly, it can introduce foreign high-quality educational and teaching resources, enhance their own teaching strength, and make up for the shortage of educational resources in local normal colleges to a certain extent. Then, it may provide students with opportunities to enjoy foreign high-quality educational and teaching resources, and meet the diverse and multi-level educational needs of local students. Secondly, in the process of implementing the project of Chinese-foreign cooperation in running school, the local normal colleges can learn the advanced school-running ideas, educational management system and educational methods of foreign higher education. At the same time, it digests and innovates them in accordance with the actual situation to develop their own characteristics. In addition, through the project of Chinese-foreign cooperation in running school for applied majors in local normal colleges, high-quality innovative internationalized talents will be trained for the construction of local free trade zone.

\section{The Necessity of International Talent Training in Local Normal Colleges}

Internationalization of Higher Education Talent Training Is the Trend of Opening Up of Local Economy. In 2016, the State Council decides to establish China (Henan) free trade experimental zone, covering districts of Zhengzhou, Luoyang and Kaifeng, which poses new challenges to the international talent training of local colleges and universities. While introducing high-quality 
foreign education resources, let the high-quality talents go out, promoting the two-way opening of local higher education. Thus, it meets the needs of local economic development based on the national strate gy of Belt and Road. The project of Chinese-foreign cooperation in running schools is the foothold of promoting the two-way opening of local higher education. The cooperative education of international applied talents training presents a multi-level structure, and local colleges and universities are increasingly becoming the main body of Chinese-foreign cooperation in running schools.

By 2018, Henan Province has four Chinese-foreign cooperative education institutions, and 110 Chinese-foreign cooperative education projects with undergraduate degree or above. And there are one Chinese-foreign cooperative education institution, and 13 Chinese-foreign cooperative education projects for higher vocational education. Henan local colleges and universities have made considerable progress in the number of Chinese-foreign cooperative school-running projects, but there are still some colleges and universities that have not opened the higher education to the outside world, existing certain development potential. While local colleges and universities have become the main body of international talent cultivation, the problems of humanistic literacy and cross-culture of cooperatively-run students have become increasingly prominent, which puts forward new topics and requirements for cooperatively-run projects of local normal colleges.

The International Talent Training of Applied Majors Is the Inherent Needs of the Development of Local Normal Colleges. "The higher education law of China" indicates that the state encourages and supports international exchanges and cooperation in culture, education and science and technology between domestic institutions and overseas institutions of higher education. It includes cooperation in running schools, exchange of lecturers studying abroad, participation in foreign academic activities, holding international academic seminars, international scientific research cooperation, etc. At the end of the 20th century, developed countries such as Europe, North America, Australia and Japan launched a new round of international talent training for higher education by adjusting talent training objectives, optimizing talent training programs, adjusting curriculum system and changing teaching methods (Bodycott, et al., 2014; Drake, 2014) [1,2]. For example, the talent training goal of Harvard University is "world citizenship", and its development strategy is internationalized talent training (Mendoza and Matyok, 2013; Waistell, 2011) [3,4]. The main parts of international education consist of education studying abroad, learning international courses, contacting with international students, attending the activities of international exchanges, and intercultural interaction (Parsons, 2010) [5].

Therefore, international cooperation education is the inherent need of international talents training in local normal colleges. International courses and cross-cultural exchanges are the main ways of international talent training in local normal colleges. Local normal colleges should make full use of national policies and their own advantages to carry out multi-level and diversified projects of Chinese-foreign cooperation and exchange so as to cultivate innovative and applied talents for local economic development.

There Is a Structural Contradiction between Supply and Demand in the Local Talent Market. According to data released by the ministry of education, there are 8.2 million Chinese college graduates in 2018. Despite there is seemingly large number of graduates, multinational corporations and Chinese companies with global ambitions have found that few graduates have the necessary skills to serve the export industry. On the one hand, it is difficult for college graduates to find jobs. On the other hand, there is a serious shortage of high-quality skilled talents. Taking the chip industry as an example, the demand for talents is 700,000 according to the total output value of the industry, and the gap of chip talents is as high as 400000. The problem of unreasonable professional structure setting in Chinese universities and the low quality of graduate vocational skills is still very prominent. In view of the problem that the specialty setting of local colleges and universities does not match the development of the ind ustrial chain, and the professional teaching are out of line of corporate requirements, the ministry of education, the national development and reform commission 
and the ministry of finance jointly issued "the guiding opinions on guiding some local undergraduate universities to change into the application-oriented Type" in 2015. It aims to lead a group of qualified local undergraduate colleges to transition to applied colleges from a policy perspective.

Under the background of college transformation, the applied major of local normal colleges should change the solidified education mode and strengthen the structural reform of talent supply side. Thus, it can cultivate the applied technical talents who are facing employment, favored by the market, urgently needed by the industry and recognized by enterprises through school-enterprise cooperation, integration of industry and education, and Chinese-foreign cooperation in running schools.

\section{The Problems of the International Talent Training in Local Colleges and Universities}

At present, there are still some problems in the international talent training for applied majors in local colleges and universities, such as the difficulty in choosing the object of cooperation in running schools, the lack of effective integration of internationalization and localization, the relatively low overall quality of students, the unreasonable orientation of training objectives, the incoherence of curriculum system, the need to improve the level of teachers, and the need to strengthen the professional education management team.

It Is Very Difficult to Screen the Objects of Cooperative School-running. The orientation of international talent training of applied major in local normal colleges is to serve local economy. The goal of talent training is connected with the construction of local free trade zone, the major setting is matched with the development of local industrial chain, and the training level is consistent with local employment demand. It aims to cultivate high-quality skilled talents with an international perspective. This requires the partners of the cooperative school-running project to have a high level of vocational ability training, excellent teacher resources and advanced skills training equipment, on the other hand, to match the local college as far as possible in the school-running concept, professional characteristics and educational management mode. In practice, when choosing cooperative school-running objects, the factors such as the restrictions of time and space, adverse selection caused by information asymmetry, cultural and linguistic differences, etc., increase the difficulty of screening cooperative objects. It is often found that cooperative objects are not ideal afterwards, and even these lead to the failure of cooperative projects.

Internationalization and Localization Lack Effective Integration. The purpose of Chinese-foreign cooperation in running schools in local colleges and universities is to introduce and absorb high-quality educational and teaching resources, scientific and reasonable curriculum system, good knowledge content structure and advanced experience of student education management from developed countries. Then, the integration of localization would be carried out to cultivate high-quality and innovative international talents for local economic and social development. Now, the Chinese-foreign cooperation in running schools has entered the development stage of improving quality and efficiency and enhancing capacity. In 2019, the ministry of education proposes to build 10,000 national first-class undergraduate majors and 10,000 provincial first-class undergraduate majors, i.e., two-ten-thousand plans. At present, some local Chinese-foreign cooperative education institutions and projects pursue economic benefits blindly. The curriculum system is introduced in an all-round copied and duplicated way, ignoring their own discipline advantages and local characteristics. Thus, they fail to fully comply with the objectives of the new era's school-running policy and the actual situation of local colleges.

The Overall Quality of Students Is Relatively Low. The internationalization of Chinese-foreign cooperative education includes two aspects: the internationalization of the teaching staff and the nationalization of students. This puts forward higher requirements not only for the teachers and education managers, but also for the professional quality and foreign language level of students. 
The project of Chinese-foreign cooperation in running schools puts forward the standard of "one third of four" for foreign courses, professional core courses, foreign teachers and teaching hours. Under the talent training modes of $3+1$ and $2+2$, students need to live and study abroad in the last one or two years, which requires students to have good international environment adaptability and language communication ability. In recent years, due to the popularization of higher education in China, local colleges and universities have been expanding their enrollment of undergraduates on a large scale, and even some families with better economic conditions directly send their children abroad to go to colleges and universities. As a result, the source of students in some local colleges and universities has declined gradually, their foreign language ability is not high and the overall quality of students is relatively low.

At present, local colleges and universities in China are carrying out Chinese-foreign cooperative education activities in full swing. However, the conventional mode of international education for students has not yet formed. There are still great challenges in cross-cultural integration. We need to continue to build an international education platform, innovate the training path of international talents, and infiltrate the elements of international teaching into all aspects of talent training process.

\section{Innovative Path of International Talent Training in Local Normal College}

Carefully Selecting Cooperative School-running Objects and Promoting the Integration of Educational and Cultural Concepts. The training of international talents for applied majors in local normal colleges should be guided by the "Regulations on Chinese-foreign Cooperation in Running Schools" issued by the ministry of education, and implement the project of Chinese-foreign cooperation in running schools with the development philosophy of improving the quality and efficiency, serving the overall situation and enhancing the ability. Based on the core criteria of improving teaching quality and enhancing the benefits of serving regional economic development, we carefully select foreign applied majors as cooperative objects. We learn the advanced teaching ideas and management modes of the partners in line with the concept of self-running schools. Thus, the foreign first-class experience can be practiced on the regional soil of China. Eventually, it helps us seek the innovative path of local higher education reform.

The process of internationalization of applied majors in local normal colleges is a two-way. In the process of implementing Chinese-foreign cooperative school-running projects, we should not only learn and absorb the advanced educational ideas of partners, but also actively export our own good educational and cultural ideas. The Chinese-foreign cooperation in running schools is the most effective way for local colleges and universities to participate in the formulation of international standards and make our own educational and cultural ideas enter the world. In the process of standardizing and innovating institutional culture, we should explore the cooperation of different education and culture in international talent training and promote the integration of multi-cultures.

Broadening the Training Path of International Talents Guided by Industry, Education, Research and Application. In the integration of education methods of industry, education, research and application, local normal colleges take scientific research projects and international cooperation projects as platforms to inherit cultural and academic research, and cultivate applied international talents. Therefore, we achieve the coordinated development of academic research level and students' practical ability, and promote relationship between scientific research and and teaching. In the practice of teaching, students should be taught in accordance with their aptitude and managed in different categories. The students are allowed to participate in teachers' scientific research projects or Chinese-foreign cooperative projects. In the scientific research activities, we train students' hands-on operation ability, and cultivate their innovative ability. Through the international cooperation projects, students would be trained jointly to broaden their international horizons. It may provide skilled human resources for local export-oriented industries.

In the process of Chinese-foreign cooperation in running schools, students' innovative thinking 
and practical skills are effectively trained under the guidance of industry, education, research and application, and students' teamwork ability is developed in an all-round way. Thus, it improves the academic research level of local normal colleges and cultivates innovative international and compound talents.

Combining Student-based Model with Teacher-based Model to Cultivate Students' International Adaptability. "Student-based model" means that the educational method of Chinese-foreign cooperation in running schools respects the development law of practical skills of applied-oriented students and takes students as the core to carry out international talent training activities. However, some scholars believe that teachers are the implementers of applied international talent training, responsible for preaching, teaching, dispelling puzzles and imparting knowledge to students, and students as educatees are in a subordinate and dependent position in international teaching activities. It should be teacher-oriented, namely, the "teacher-based model". In the teaching activities of Chinese-foreign cooperative projects, students' critical thinking and internationalized practical skills should be trained. In case analysis, group discussion and skill training, it is necessary to carry out the design and careful guidance of teachers. We should give full play to teachers' leading core in international talent training activities.

As students are the main body of Chinese-foreign cooperative activities, we should give full play to students' subjective initiative, be good at listening to their doubts, and pay attention to the cultivation of students' ability to raise and analyze problems. The relationship between teachers and students is similar to that between referee, coach and athlete. With teachers as the leading role, and students as the main body, we innovate the interactive teaching activities to improve students' international adaptability.

Constructing a Scientific and Reasonable Talent Evaluation System. The purpose of Chinese-foreign cooperative education in local colleges is to train internationalized applied talents, serving the local economic and social development. We evaluate the quality of talents in the practice of social services and local economic development. Ultimately, the market has the final say. The scientific talent evaluation system not only includes elemental indicators such as ideological and moral cultivation, scientific and cultural knowledge, innovation and entrepreneurship ability, international management coordination and other key indicators, but also combines the local ind ustrial structure and characteristics to formulate different categories and different levels of talent evaluation indicators. It should give full play to the participation of third-party talent evaluation institutions. In particular, the cultivated talents should have humanistic quality, professional quality and international vision.

In constructing a scientific talent evaluation system, we should combine qualitative and quantitative evaluation method, coordinate the external explicit value and implicit value of talent, and handle the boundaries of self-evaluation and social evaluation. It should evaluate the trained talents scientifically and reasonably with objective, fair, open and transparent standards.

\section{Conclusions}

With the deepening of the opening up of higher education in the new era, the applied majors of local normal colleges need to cultivate internationalized skilled talents with humanistic qualities and serving local economic development. How to innovate the training path of international talents in local normal colleges, improve the humanistic quality of international cooperative education students, and cultivate high-level skilled talents with national feelings and international vision has put forward new requirements for the projects of cooperation in running schools of local normal colleges.

The project of Chinese-foreign cooperation in running schools is the most effective way for local normal colleges to participate in the formulation of international educational rules and promote their own cultural ideas to the world. In the process of standardizing and innovating institutional culture, 
local normal college should make full use of national policies and professional characteristics to carry out multi-level and multi-category Chinese-foreign cooperation and exchange projects, actively explore different modes of cooperation between education and culture, and promote the exchange and integration of multi-cultures.

\section{Acknowledgments}

This work was supported by the Young Backbone Teacher Training Plan Foundation of Colleges and Universities of Henan Province (No. 2018GGJS132), the Young Backbone Teacher Training Plan Foundation of Luoyang Normal University and the Science and Technology Innovation Talent Support Plan Foundation of Colleges and Universities of Henan Province (No. 2020-cx-007).

\section{References}

[1] P. Bodycott, A. Mak, P. Ramburuth, Utilising an internationalised curriculum to enhance students' intercultural interaction, engagement and adaptation, Asi-Pacific Education Researcher. 23 (2014) 635-643.

[2] H. Drake, Learning from peers: The role of the student advisor in internationalising the European studies curriculum, European Political Science. 13 (2014) 12-22.

[3] H. Mendoza, T. Matyok, Designing student citizenship: Internationalised education in transformative disciplines, International Journal of Art\&Design Education. 32 (2013) 215-225.

[4] J. Waistell, Individualism and collectivism in business school pedagogy: A research agenda for internationalising the home management student, Higher Education Research\&Development. 30 (2011) 595-607.

[5] R. Parsons, The effects of an internationalized university experience on domestic students in the United States and Australia, Journal of Studies in International Education. 14 (2010) 313-334.

[6] Y. Ma, Y. Xu, Study on talent training model in universities under the background of Chinese-foreign cooperation in running schools, Journal of Hebei University of Science and Technology. 16 (2016) 108-112.

[7] Q. Jiang, Q. Xu, Integration of international talent cultivation system of the construction of the Research and practice, Journal of Educational Institute of Jilin Province. 33 (2017) 110-113.

[8] L. Cheng, X. Shao, Construction of curriculum system in Chinese-foreign cooperative education from perspective of system theory, Heilongjiang Researches on Higher Education. 7 (2017) $163-166$. 